Article

\title{
The Potential of RES in the Reduction of Air Pollution: The SWOT Analysis of Smart Energy Management Solutions for Krakow Functional Area (KrOF)
}

\author{
Tomasz Jeleński $^{1, *(\mathbb{D}}$, Marta Dendys ${ }^{2}$ (D) Barbara Tomaszewska $^{2}$ and Leszek Pająk ${ }^{2}$ \\ 1 Faculty of Architecture, Cracow University of Technology, 24 Warszawska St., 31-155 Kraków, Poland \\ 2 Faculty of Geology, Geophysics and Environmental Protection, AGH University of Science and Technology, \\ 30 Mickiewicza Al., 31-155 Kraków, Poland; mdendys@agh.edu.pl (M.D.); \\ barbara.tomaszewska@agh.edu.pl (B.T.); pajakl@agh.edu.pl (L.P.) \\ * Correspondence: tjelenski@pk.edu.pl; Tel.: +48-601-400-395
}

Received: 28 February 2020; Accepted: 30 March 2020; Published: 6 April 2020

check for updates

\begin{abstract}
Health impacts and a decrease in the quality of life caused by air pollution is a major problem worldwide. Krakow is one of the most affected cities in the EU by air pollution mostly caused by burning solid fuels in households' furnaces. It is considered that the most effective remedies would be adequate spatial planning solutions and application of low-emission sources including renewable energy sources (RES). This article draws from the analysis of the use of RES as a means for reducing harmful emissions in Krakow Functional Area (KrOF). The inventories of renewable energy sources and systems were compiled by the authors as a part of the EU project "Smart Edge-Sustainable Metropolitan Areas and the Role of The Edge City". Using the data from the inventories, a SWOT analysis has been carried out to identify factors that determine the smart management of the RES potential, particularly the decisions of households on the transition towards RES. The results of the analysis have shown that many actions have been taken at the national, regional, and local levels but the greatest influence bear the solutions initiated and implemented at the communal level. The conclusion is that legislative regulations should be combined with locally tailor-made instruments. The proposed method of analysis can be applied in other metropolitan areas as a diagnostic procedure supporting action planning to solve air-quality problems caused by distributed emission sources.
\end{abstract}

Keywords: air pollution; clean energy; distributed energy sources; layperson point of view; metropolitan area; renewable energy sources; smart governance; sustainable urban development; SWOT analysis

\section{Introduction}

Renewable energy installations are implemented for many reasons, but two of them seem to be the most important. The first is related to the energy branch. Oil, natural gas, and coal are limited resources whilst renewable energy sources (RES) are sustainable alternatives for them. The second but even more urgent reason is the environment, including the climate. Burning fossil fuels causes harmful emissions into the atmosphere, contributing globally to climate change and locally to the ambient air pollution which is a major cause of death and disease globally [1].

The purpose of this article is to analyse the most effective spatial planning and governance solutions to popularise low-emission energy sources including RES as a means for reducing air pollution in the Krakow Functional Area (KrOF). It is also the authors' goal to describe the proposed method of analysis so it could be applied in other metropolitan areas as a diagnostic procedure supporting action planning. 
According to the European Environment Agency Report [2], Europe's most serious pollutants in terms of risk to health, are particulate matter $(\mathrm{PM})$, nitrogen dioxide $\left(\mathrm{NO}_{2}\right)$, and ground-level ozone $\left(\mathrm{O}_{3}\right)$. Estimates of the health impacts connected to exposure to air pollution indicate that $\mathrm{PM}_{2.5}$ concentrations in 2015 were responsible for about 422,000 premature deaths originating from long-term exposure. The report [2] shows that Poland is among the most polluted countries in the EU. The biggest problem in Poland urbanised areas concerns $\mathrm{PM}_{10}$ and $\mathrm{PM}_{2.5}$, as well as benzo(a)pyrene (B(a)P), and $\mathrm{NO}_{2}$. Both $\mathrm{PM}$ and $\mathrm{B}(\mathrm{a}) \mathrm{P}$ concentrations exceed the safety levels in many urban areas, including small towns. The dominant source of $\mathrm{PM}$ and $\mathrm{B}(\mathrm{a}) \mathrm{P}$ are household boilers burning coal and wood [3]. $\mathrm{NO}_{2}$ problems occur in major cities, including Krakow [4] (Figure 1a). The dominant source of $\mathrm{NO}_{2}$ is car traffic which is the largest in the bigger cities. The traffic is also the cause of secondary emissions of $\mathrm{PM}$ at ground level which are often more harmful than emissions from other sources.

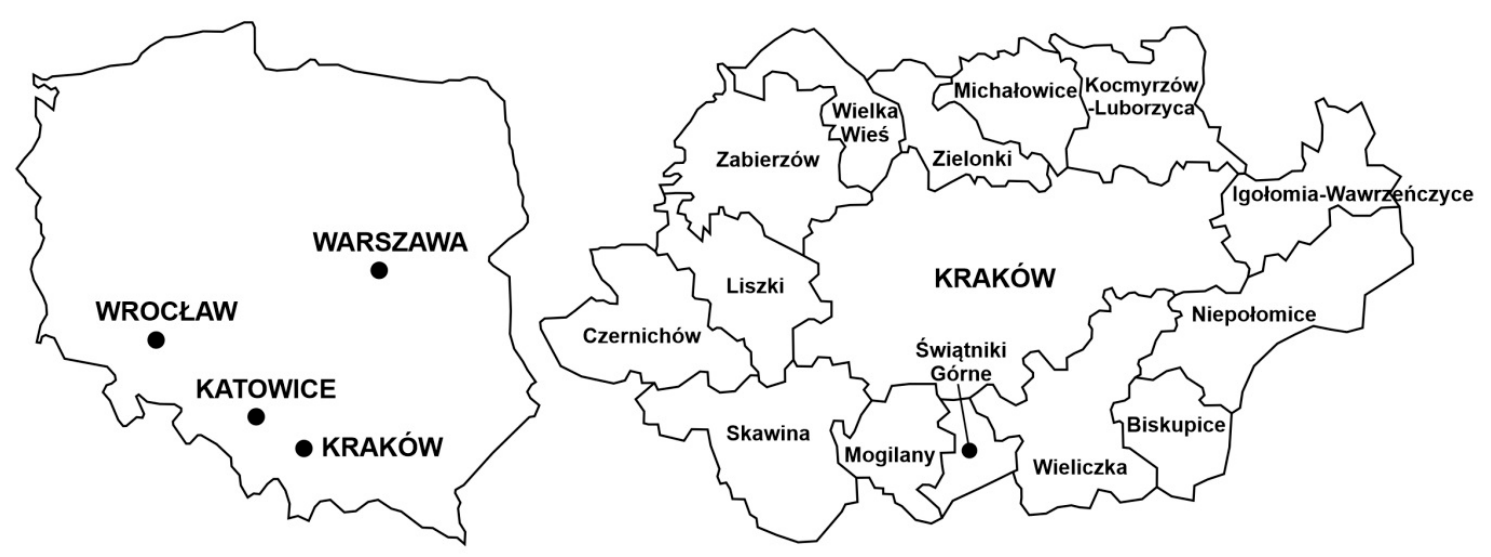

(a)

(b)

Figure 1. (a) Location of major Polish cities on the map of the country. (b) Krakow Functional Area (KrOF) - the City of Krakow and 14 other municipalities cooperating under Krakow Metropolis Association (KMA).

The use of RES in cities is widely discussed in the broad context of sustainable urban development [5-7]. In Poland, this discussion has recently been invigorated, and now Polish municipalities' ambition is to join leading cities in Europe in the development of smart energy solutions. Krakow - the second largest and one of the most developed cities in Poland-is also one of the most affected by air pollution in the EU (Figure 1a). The problem concerns the whole KrOF-consisting of the City of Krakow and 14 municipalities that surround the city (Figure 1b).

The Regional Inspectorate for Environmental Protection (RIEP) provides detailed data on the spatial distribution of air pollutants (Table 1). The air quality in $\mathrm{KrOF}$ exceeds safe levels set in air quality standards for particulate matter $\left(\mathrm{PM}_{10}\right)$ and $\left(\mathrm{PM}_{2,5}\right), \mathrm{B}(\mathrm{a}) \mathrm{P}$, as well as $\mathrm{NO}_{2}$ which all have a direct impact on human life and health. This is primarily caused by the surface sources from municipal and household pollution (but mainly from residential buildings' heating systems) - see Figure 2 [8]. The PM inflow from neighbouring communes has a significant contribution to air pollution in the core City of Krakow (about $39 \%$ for $\mathrm{PM}_{10}$ ).

Table 1. Air pollution in $\mathrm{KrOF}$ [9].

\begin{tabular}{|c|c|c|c|c|c|c|c|c|c|c|c|c|}
\hline \multirow{2}{*}{$\begin{array}{c}\text { Zone } \\
\text { Krakow Urban }\end{array}$} & \multicolumn{12}{|c|}{ Class of Pollutions-Human Health Protection Criteria } \\
\hline & $\mathrm{SO}_{2}$ & $\mathrm{NO}_{2}$ & $\mathrm{CO}$ & $\mathrm{C}_{6} \mathrm{H}_{6}$ & $\mathrm{O}_{3}$ & $\mathrm{PM}_{10}$ & $\mathrm{PM}_{2,5}$ & $\mathrm{~Pb}$ & As & $\mathrm{Cd}$ & $\mathrm{Ni}$ & $\mathrm{B}(\mathrm{a}) \mathrm{P}$ \\
\hline Agglomeration & $\mathrm{A}^{1}$ & $C^{2}$ & A & A & A & $\mathrm{C}$ & $\mathrm{C}$ & A & A & A & A & $\mathrm{C}$ \\
\hline
\end{tabular}

${ }^{1}$ Class A-the level of pollution does not exceed the permissible or target level. ${ }^{2}$ Class C-the level of pollution exceeds the acceptable or target level. 


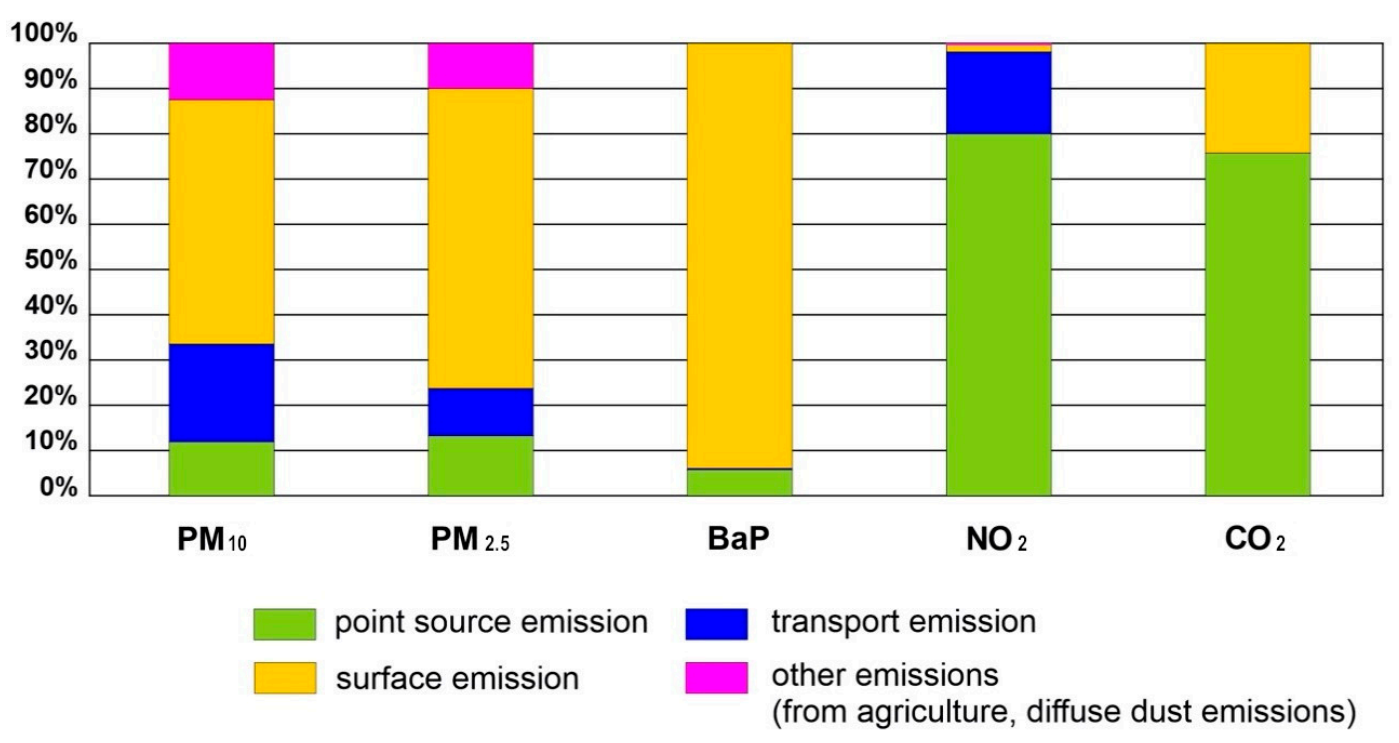

Figure 2. Emission values of $\mathrm{PM}_{10}, \mathrm{PM}_{2.5}, \mathrm{~B}(\mathrm{a}) \mathrm{P}, \mathrm{NO}_{2}$, and $\mathrm{CO}_{2}$ by source type in the Region of Małopolska, in 2015 [8] (p. 34).

This problem has been addressed in several strategic documents on the regional, metropolitan, and local levels. The Development Strategy of the Małopolska Region 2011-2020 [10] (p. 121-122) recommends increasing the utilisation and promotion of RES substantially. The strategy recommends identifying the existing and potential development barriers, and determining the direction of the regional policy of renewable energy development as one of the key actions.

The Małopolska Spatial Development Plan (PZPWM) [11] (p. 76) indicates the need to shape compact urban structures that minimise energy demand and increase the use of RES. In the development scenarios, increased demand for energy is expected, but also greater opportunities for prosumer energy and the use of RES. PZPWM, therefore, provides for a gradual increase in the share of energy from RES, but only to achieve the level assumed in the Renewable Energy Directive [12]. The plan assumes creating conditions and mechanisms aimed at increasing the share of renewable energy generated in the region from $9.5 \%$ in 2015 to $15 \%$ in 2022, in particular, based on solar energy, biogas and biomass combustion, efficient energy use (including thermal modernisation of buildings and RES heating), and improving the system of organisational, educational, and financial solutions.

Since the air pollution is a major problem for $\mathrm{KrOF}$, it is noted in the Strategy for KrOF Integrated Territorial Investment (KrOF ITI) [13] that the quality of air might be improved by the development of RES. This positive effect, however, does not apply to the combustion of biomass which often causes high emissions of PM. For this reason, the total prohibition of all solid fuels, including biomass, has been introduced in Krakow in September 2019 [14].

One of the priorities of KrOF ITI is the overall transition to a low-carbon economy, including the thermal modernisation of buildings, smart energy management, and the use of RES. However, among the indicators adopted in the strategy for KrOF ITI, there is none that would allow the direct control of RES development.

Some of the data can be obtained from the Energy Regulatory Office (URE). According to them, RES technologies that dominate in $\mathrm{KrOF}$ are based on biogas, multi-fuel combustion (with biomass), and thermal waste treatment [15]. Companies that use biomass, also produce energy from burning various fuels in cogeneration of heat and electricity in one technological process [16-18]. This technology is popular due to energy efficiency, the ability to reduce greenhouse gas emissions, and the possible utilisation of RES [19].

Heat and energy producers in Krakow co-burn biomass with coal, natural gas, heating oil, and other fossil fuels. The biggest 16 companies located in KrOF produce electricity with total installed power that equals 922,601 MWe (Table 2). 
Table 2. Share of renewable energy sources (RES) in energy production in KrOF [15].

\begin{tabular}{cccc}
\hline Source of Energy & Number of Units & Installed Capacity [MWe] & Share \\
\hline Total & 16 & 922.701 & $100 \%$ \\
\hline Non-renewable & $\mathbf{5}$ & $\mathbf{4 4 2 . 0 5 3}$ & $\mathbf{4 7 . 9 \%}$ \\
\hline Renewable & $\mathbf{1 1}$ & $\mathbf{4 8 0 . 6 4 8}$ & $\mathbf{5 2 . 1} \%$ \\
\hline Biogas & 3 & 3.498 & $0.4 \%$ \\
\hline Biomass (co-incineration) & 3 & 466.900 & $50.6 \%$ \\
\hline PV & 1 & 0.060 & $0.0 \%$ \\
\hline Wind & 0 & 0.000 & $0.0 \%$ \\
\hline Hydro & 4 & 10.190 & $1.1 \%$ \\
\hline Geothermy & 0 & 0.000 & $0.0 \%$ \\
\hline
\end{tabular}

In $\mathrm{KrOF}$, five entities have a license for heat generation (Table 3). The total thermal power of 53 generating units located in the cities of Krakow and Skawina equals $1581.310 \mathrm{MWt}$ [15]. None of the 53 units can be defined as an installation that uses 100\% RES.

Table 3. Share of RES in heating production in $\mathrm{KrOF}$ [15].

\begin{tabular}{lllll}
\hline \multicolumn{1}{c}{ Licensed Entity } & Location & Type of Production & \multicolumn{1}{c}{ Fuel } & $\begin{array}{c}\text { Installed Thermal } \\
\text { Power [MW] }\end{array}$ \\
\hline CEZ Skawina SA & Skawina & $\begin{array}{l}\text { Multi-fuel combustion } \\
\text { installation, steam } \\
\text { boilers, cogeneration }\end{array}$ & $\begin{array}{l}\text { Coal, Heavy oil, Biomass from } \\
\text { products, waste and residues of } \\
\text { industry processing agricultural } \\
\text { products }\end{array}$ & 946.600 \\
\hline $\begin{array}{l}\text { Krakowski Holding } \\
\text { Komunalny SA }\end{array}$ & Kraków & $\begin{array}{l}\text { Thermal waste treatment } \\
\text { installation, steam } \\
\text { boilers, cogeneration }\end{array}$ & $\begin{array}{l}\text { Non-hazardous waste } \\
\text { containing biodegradable } \\
\text { fractions, Fuel oil }\end{array}$ & 69.000 \\
\hline $\begin{array}{l}\text { Miejskie Przedsiebiorstwo } \\
\text { Energetyki Cieplnej SA, }\end{array}$ & Kraków & Boiler rooms-49 units & Natural gas, Fuel oil & 27.710 \\
\hline $\begin{array}{l}\text { TAMEH Polska Sp. z o.o., } \\
\text { Dabrowa Górnicza }\end{array}$ & Kraków & $\begin{array}{l}\text { Steam boilers, } \\
\text { cogeneration }\end{array}$ & $\begin{array}{l}\text { Blast furnace gas, Coal, Coke } \\
\text { gas, Natural gas }\end{array}$ & 538.000 \\
\hline $\begin{array}{l}\text { PGE Energia Ciepła SA, } \\
\text { Warszawa }\end{array}$ & Kraków & $\begin{array}{l}\text { Water boilers, steam } \\
\text { boilers }\end{array}$ & $\begin{array}{l}\text { Hard coal, Light heating oil, } \\
\text { Biomass from products, waste } \\
\text { and residues from agricultural } \\
\text { production and industry } \\
\text { processing agricultural products }\end{array}$ & 1644.000 \\
\hline
\end{tabular}

\subsection{National and Regional Policy Goals}

Pursuant to the EU directive [12], the National Renewable Energy Action Plan 2020 (KPD) [20] was adopted in Poland in 2010. The plan defines the targets and the measures to be taken to increase the share of renewable energy in the use of final energy, considering the general objective of achieving a $15.5 \%$ share of renewable energy in gross final energy consumption in 2020. KPD also lists support systems for the promotion of the use of energy from renewable sources and defines the principles of cooperation between local, regional, and national authorities to increase the use of renewable energy. In this context, it was emphasised that public buildings need to set the benchmark use of renewable energy and be the exemplars of transformation into zero energy buildings [21].

The most recent National Energy and Climate Plan (NECP) for the years 2021-2030 [22] sets the following climate and energy goals for 2030:

- $-7 \%$ reduction in greenhouse gas emissions in non-ETS sectors compared to 2005 levels,

- the share of coal in electricity production to be reduced to $56 \%-60 \%$,

- $21 \%-23 \%$ share of renewable energy sources in final gross energy consumption. 
Although distributed heating installations are the main source of air pollution in Poland, it needs to be noted that NECP does not consider the most common segment of the heating sector-non-system, individual heating - and does not present appropriate policies and measures for it. There is also a lack of reference in NECP to the potential benefits of coordination between the entire district heating sector (system and non-system) and the national power sector [23].

The Małopolska Spatial Development Plan (PZPWM) [11] (p. 76) indicates the need to shape compact urban structures that minimise energy demand and increase the use of RES. In the plan's development scenarios, an increased demand for energy is expected, but also greater opportunities for prosumer energy and the use of RES. PZPWM, therefore, provides for a gradual increase in the share of energy from RES, but only to achieve the level assumed in Directive 2009/28/EC. The plan assumes creating conditions and mechanisms aimed at increasing the share of renewable energy generated in the region from $9.5 \%$ in 2015 to $15 \%$ in 2022, in particular, based on solar energy, biogas, and biomass combustion, efficient energy use including thermal modernization of buildings and RES heating, as well as improving the system of organisational, educational, and financial solutions.

The goals related to renewable energies in buildings are also indirectly included in the Air Quality Plan for Małopolska Region 2017 (MAQP) [8], in the sections regarding the introduction of restrictions on the use of solid fuel installations; the elimination of low-efficient heating devices; the expansion and modernization of heating and gas networks ensuring the connection of new users; the use of RES to reduce operating costs of energy; thermal modernisation of buildings; and support for energy-saving housing. MAQP specifies the required environmental effects: Reduction of $\mathrm{PM}_{10}, \mathrm{PM}_{2,5}, \mathrm{~B}(\mathrm{a}) \mathrm{P}$, and $\mathrm{CO}_{2}$ emissions in 2017-2019 and 2020-2023, allocated to individual municipalities [mg/year].

The draft Development Strategy of the Małopolska Region (DSMR) [24] is currently under public consultations. The air quality improvement is set to be the most important direction of development policy. It is to be implemented mostly by thermal modernisation of buildings, which is also an element of economical energy management. A new urban development model is defined in the strategy too, which limits the spread of suburban buildings. The model is supported by several urban planning paradigms, such as a mix of uses and transit-oriented development (TOD) [24].

The third main direction of the DSMR is renewable energy and energy efficiency.

The specific goals are, among others:

- Increasing the use of technologies based on RES to produce heat, cold, and electricity;

- Improving the energy efficiency of the public sector and housing through thermal modernisation of buildings as an element of economical energy management;

- Development of energy-saving building;

- Promotion and education in the field of lifestyle change towards energy saving and reducing its consumption.

The strategy perceives the need to develop smart energy grid mechanisms in the context of monitoring. As an important element of the strategy for the development of renewable energy and the energy efficiency improvement, intensive education and promotion of related issues are indicated as well as the system of eco-advisors, to increase society's awareness of the importance of RES and to promote economic management of energy [24].

Indicators of achieving the main objective and specific objectives include an increase of $8.4 \%$ in the share of renewable energy in total energy production in the region.

The strategy stresses an important role to be played by the Krakow Metropolis Association (KMA), in creating a cooperation platform for 15 associated municipalities of KrOF that jointly implement integrated territorial investments (ITI).

\subsection{The Concept of Smart Metropolis}

The term "smart city" is widely used since the mid-1990s and evolves towards a strong integration of human intelligence, collective intelligence, and an effective combination of information and 
communications technology (ICT). The fundamental notion about smart management of cities and metropolitan areas is sustainable development as the organizing principle for meeting economic, social, and environmental goals. Thus, it requires a unique set of frameworks (human, institutional, technology, energy, and data management) as well as established institutions of community-based problem solving and collaborations for holistic recognition and comprehensive solutions [25]. While information technologies are actively used in all spheres of life, including various services, the smart city remains an idea that never matured as a theoretical construct or practical implementation. As an open concept, it needs to be continuously enhanced to address old and new challenges of integrated urban management [26,27].

The need for low-carbon development remains the fundamental challenge for metropolitan regions. That challenge concerns all kinds of infrastructure as well as buildings, machinery, society, individuals, and governance [28]. Renewable sources of energy are among the most promising solutions for the problems of pollution, the scarcity of resources, and other problems generated by the fossil fuel economy. The transition to RES is a complex challenge which, from the point of smart city, concerns various conditions for producers, prosumers, and grids: The legislature, incentives to prosumer investments [29], principles of settling with grid operators, organisation of the energy cooperatives, and overall managerial culture of smart distributed energy generation.

\subsection{Smart Metropolis Concept for KrOF: The Role of Krakow Metropolis Association}

Since air pollution is not a kind of problem which could be solved locally on the territory of the core city or any of the communes which surround it, it was decided to undertake broader cooperation at the metropolitan level. The operator of these activities is the Krakow Metropolis Association (KMA), which creates an institutionalised platform of cooperation of 15 municipalities associated in it, which represent the City of Krakow and the surrounding 14 communes (Figure 1b). The association initiates and supervises the planning and implementation of projects co-financed from European funds under the ITI, provides expert knowledge, helps to raise funds for the joint implementation of projects, and supports actions taken by member communes for the sustainable economic, social, and cultural development of the metropolis. Since KMA increases its efforts to create an adequate infrastructure of information and management, it may be regarded as the first attempt to implementation of the smart metropolis concept in the region of Krakow.

The strategy for KrOF ITI [13] is the only strategic document setting out the goals of the KMA. Of the main importance in the context of this study is the Priority 2.1: The transition to the low-carbon economy. This includes the thermal modernisation of buildings, smart energy management, and the use of RES. However, among the indicators adopted in the strategy for KrOF ITI, there is none that would allow the direct control of RES development.

The specific low-emission targets are described in particular programmes and projects run by KMA as well as in the plan for the replacement of coal boilers in KrOF by 2022, adopted in 2018 [30]. The plan makes arrangements for inventory, management, financing, control, as well as information and promotion of activities for the liquidation of coal boilers in KrOF. The authors of this study have been involved in the KMA projects aimed to define the potential of integrated management in improving the quality of air. KMA's SmartEdge project described in the next section has provided the foundation for the analysis presented in this article.

\section{Materials and Methods}

\subsection{Inventories}

The authors of this paper contributed as external experts to the EU project "Sustainable Metropolitan Areas and the Role of The Edge City (SmartEdge)", implemented by KMA under the Interreg Europe Program. The SmartEdge project addresses the potential for greenhouse gas emission reduction in the metropolitan area, focusing on urban communes of $\mathrm{KrOF}$ outside the core 
city. Several inventories have been developed in the cause of the project, related to the smart city concept and the use of RES: Renewable energy and energy systems in buildings [31]; Economic development on the basis of renewable energies [32], and Participatory urban planning: Metropolia Krakowska current local practice [33]. This study is concentrated on processing the information gained from the SmartEdge inventories to examine the current use and potential of low-emission RES installations in KrOF.

\subsection{Good Practices}

The total prohibition of solid fuels, including biomass, was introduced in the City of Krakow in September 2019 [14]. It was preceded by the largest project of co-financing RES in the region. Residents have replaced their old boilers and heating installations with modern sources and installations that meet current emission standards. The program has funded up to $100 \%$ of investment costs [14]. Unfortunately, the program has not necessarily promoted the use of RES, nor the comprehensive thermal modernisation reducing heat consumption. Gaseous fuels and light heating oil installations have been allowed and installed on a large scale, which may for years inhibit household investment in heating systems based on RES.

By comparison, within the same KrOF, the Commune of Niepołomice implemented investment in heat pumps and PVs in its primary schools. The facilities had been thermally insulated and then equipped with complete low-emission heating installations. Smart control systems used there allow for the optimisation of the operation of heating devices depending on the weather and the needs of users.

Under the STOP SMOG program, launched by the Ministry of Entrepreneurship and Technology in mid-2019, one can receive a grant covering up to $70 \%$ of furnace replacement costs and thermal modernisation of residential buildings. A maximum of PLN 60,000 can be spent on one building.

The Commune of Skawina-one of the KrOF edge cities-was the first in Poland to implement the STOP SMOG program launched by the Ministry of Entrepreneurship and Technology in mid-2019. This is directed primarily towards the poorest residents of Skawina. By June 2022, 300 single-family buildings will undergo thermal modernisation [34].

Under the project called "Eco-partners for solar energy in Małopolska", PV panels on almost 800 private buildings in all communes of the Wieliczka poviat are subsidised. The leader of the project is the local NGO, and the municipality of Niepołomice is the coordinator of its part for Wieliczka poviat [35]. The subsidy is covering 60 percent (minus VAT) of installation costs. The residents participating in the project are covering the remaining costs-about PLN 14-15,000 per household (with an assumed gross price of up to PLN 5000 for the installation producing $1 \mathrm{~kW}$ of energy). The investment is planned for two years (until June 2021).

Thanks to the participation of the Skawina and Wieliczka municipalities in the LIFE project, the inhabitants of these communes can take advantage of the free assistance of eco-advisors. Their competencies include:

- Providing advice to residents on the replacement of heating and hot water sources (selection and optimisation of the type and power of the source) and on the entire thermal modernisation of the building (including thermal imaging),

- Providing education for residents, and organising workshops on energy-saving and ecological and health benefits from the replacement of heat sources,

- Cooperation with local media, action groups, parishes, NGOs, Volunteer Fire Brigade, Police, medical doctors, energy companies, road engineers, chambers of commerce/agriculture, etc.

In 2017, the City of Krakow, in cooperation with PGE Energia Ciepła company, implemented a system for the monitoring of media consumption in communal public buildings. The system covers 636 buildings, where all utilities are monitored: Water, electricity, heat from the municipal network, and gas. A specialised system has been used (developed by specialists from the PGE heat and power plant in Kraków) to assess the energy efficiency of buildings. The assessment is provided in four key areas: Media consumption, environmental impact, energy efficiency, and costs. In communal buildings, 
consumption of heat, gas, electricity, and water is monitored. These activities bring measurable financial effects: In 2018, the total cost of media consumed in the monitored buildings dropped by almost PLN 700,000 compared to 2017 [36].

All KrOF municipalities develop and implement sustainable energy and climate action plans (SECAPs) and low carbon economy plans (PGNs). They elaborate audits and energy performance certificates of municipal buildings, and SWOT analyses of the local energy situation; implement energy-focused investments reducing emissions and costs of energy consumption in schools and other municipal buildings; activate local communities; employ eco-advisors, and organise energy days. They also cooperate with partners from other regions and from other EU countries.

All the edge cities of $\mathrm{KrOF}$ implemented the project entitled "Installation of renewable energy systems in the municipalities of Niepołomice, Wieliczka, Skawina, and Miechów on public buildings and private houses" - the so-called Solar Project. As a part of it, thermal modernisation of educational and sports facilities was carried out, including modernisation of ventilation, the application of heat pumps and PVs, financed both from the communes' own resources and external sources [37].

\subsection{Organisation of Data, Generation of Arguments, and SWOT Analysis}

SWOT matrix is a universal strategic planning technique and for decades it has been successfully used to organise and analyse information in the political economy and governance [38]. The main source of data for the SWOT analysis was drawn from the inventory Economic development on the basis of renewable energies [32]. The analysis has been used as a tool for evaluation of the strategic position of the Krakow Functional Area towards the use of RES. All information has been reviewed to identify the key internal and external factors and the priority areas seen as important to achieving an objective, which is the improvement of air quality (Figure 3).

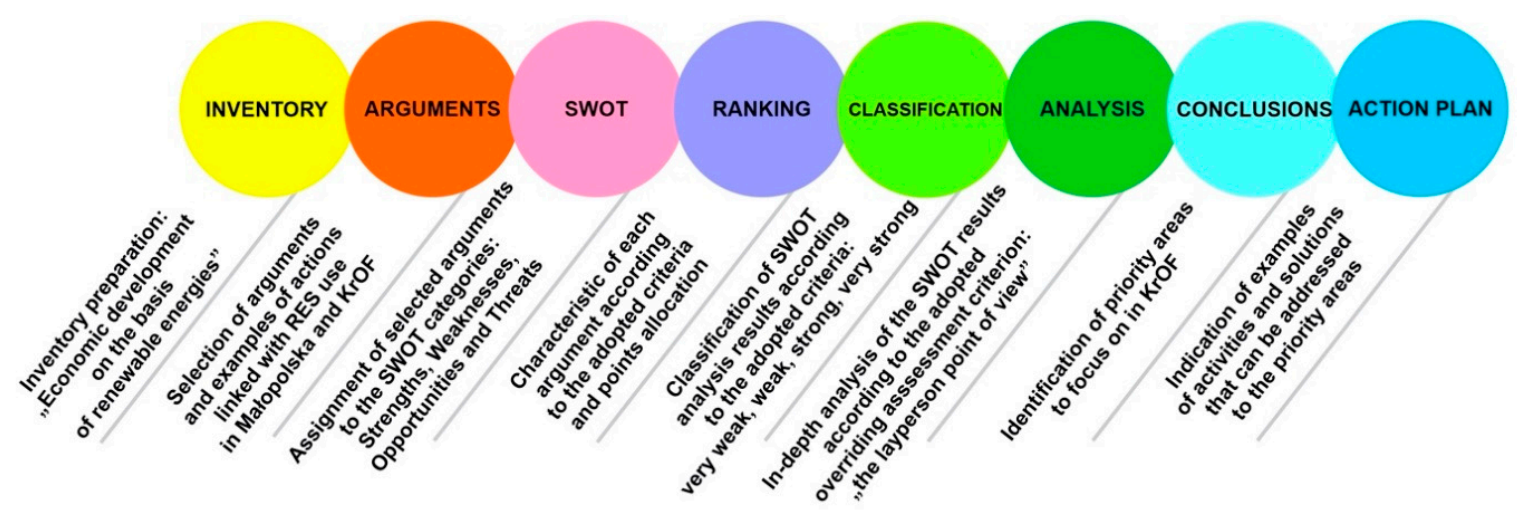

Figure 3. The following stages of analysis of information collected in the inventories [31-33].

According to the general rules of SWOT analysis, data have been divided into four categories of factors: Strengths, weaknesses, opportunities, and threats. Each factor has been assigned to the appropriate quarter of the SWOT matrix.

The main criterion of the choice and assignment of factors and arguments was "the layperson point of view" which means a viewpoint of a person who is not trained in or does not have a detailed knowledge of the subject. As it was mentioned in the introduction, the most dangerous pollution (PM, $\mathrm{B}(\mathrm{a}) \mathrm{P}$, and $\mathrm{NO}_{2}$ ) in $\mathrm{KrOF}$ is mainly a product of two types of sources: The combustion of solid fuels in household furnaces and the traffic increased by the everyday use of the private car. Both types of sources are related to individual decisions or customs of the residents: The choice of households' source of energy for heating, and the choice of individual or public urban mobility options. Thus, it is to the largest extent the sum of individual laypeople decisions that determinate mostly the air quality in $\mathrm{KrOF}$. For the success of the clean air policies, it is of fundamental importance to generate meaningful information-a set of arguments-to identify the competitive advantages of RES. According to this, 
the factors used in the SWOT matrix have the form of arguments, that is reasons or sets of reasons given in support of an idea and action towards the use of RES.

\subsection{Ranking}

In the next phase of the analysis, each factor/argument from SWOT matrix quarters has been categorised according to adopted criteria. Each factor has been assigned to one of the following groups:

1. Branch category of RES: Heating, power generation, mixed heating and power, electromobility, and general RES;

2. RES domain: Policy, finance, natural and technical conditions, education and promotion, knowledge and information, and good practice;

3. Action range: State or general (national or international scale), regional (the region of Małopolska), and local (KrOF).

Then, each argument has been evaluated according to the action impact adopted criterion of "the layperson point of view". Each of the strengths, weaknesses, opportunities, or threats has been examined in terms of impact on individual decisions of the laypeople. Each of the pieces of information has been assigned to one of two categories: (i) indirect impact or (ii) direct impact.

Table 4 shows the results according to the importance for reducing air pollutants in $\mathrm{KrOF}$ through the use of RES in households (the layperson point of view).

\subsection{Classification}

After the allocation, points from different categories have been multiplied. The minimum score possible to gain was one point. The maximum score that a factor (an argument or action) can get is 36 (Figure 4, Table 5).

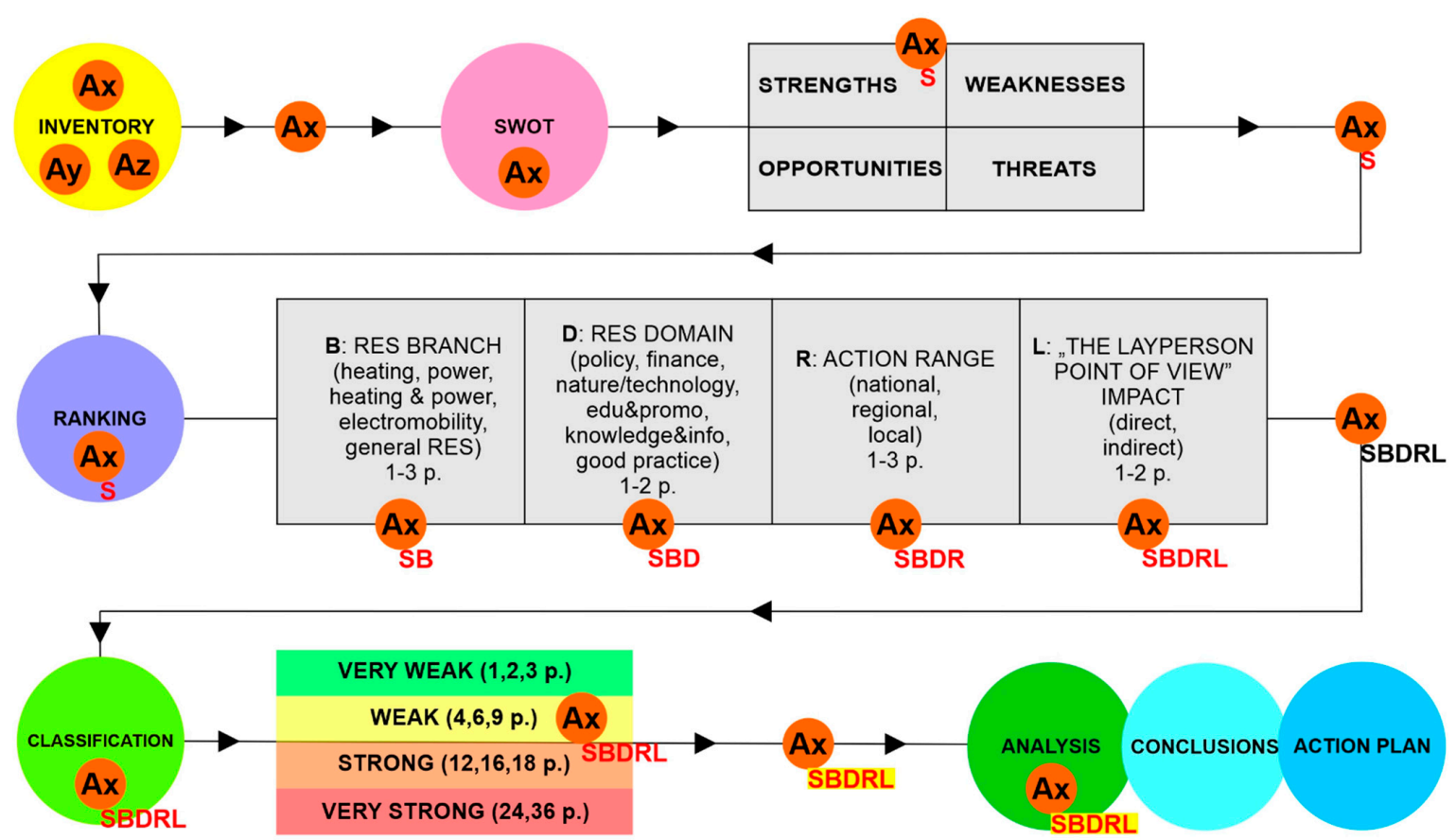

Figure 4. The methodological path for each individual argument (Ax) from an inventory, analysed according to the purpose of this study. 
Table 4. Categorisation and scoring method for each argument in the SWOT analysis.

\begin{tabular}{|c|c|c|c|}
\hline No & Name of Criterion & Abbreviation in SWOT Matrix & Points \\
\hline \multicolumn{4}{|c|}{ Branch Category of RES } \\
\hline \multicolumn{4}{|c|}{$\begin{array}{l}\text { Heating and power generation have the greatest impact on the air quality in KrOF and these categories have been valued } \\
\text { at } 3 \text { points. Mobility is next important but not only KrOF residents are responsible for vehicle exhausts. Krakow is visited } \\
\text { daily by thousands of stakeholders (employees, tourists, students, suppliers, entrepreneurs) commuting by their own cars } \\
\text { This fact has determined that to this category } 2 \text { points have been assigned. Actions related to RES generally have been } \\
\text { valued for } 1 \text { point because due to the lack of a specific reference to heating, power or electromobility category, they make } \\
\text { a smaller impact on layman decisions and households' transition towards RES. }\end{array}$} \\
\hline 1 & Heating & HTG & $3 \mathrm{p}$. \\
\hline 2 & Power & PW & $3 \mathrm{p}$. \\
\hline 3 & Mixed: Heating \& Power & MHP & $3 \mathrm{p}$. \\
\hline 4 & Electromobility & EM & $2 \mathrm{p}$ \\
\hline 5 & General RES & GR & $1 \mathrm{p}$ \\
\hline
\end{tabular}

\section{RES Domain}

In the RES domain category, 2 points have been assigned for subcategories of policy, finance, natural and technical conditions, while 1 point for arguments from the subcategories of education and promotion, knowledge and information, and good practice. All legal regulations, including the possibility of receiving financial support as well as natural conditions and technical possibilities, significantly determine decisions and affect the motivation of laypeople to install systems based on RES. Education, availability of information and/or good examples of RES implementation cause that the attitude towards possible changes is more positive. However, such an attitude does not directly affect the decisions of households to make the transition to RES. In Krakow, the majority of households have not made the decisions until the forthcoming total prohibition of solid fuels became inevitable.

\begin{tabular}{llcc}
\hline 1 & Policy & POL & $2 \mathrm{p}$. \\
\hline 2 & Finance & FIN & $2 \mathrm{p}$. \\
\hline 3 & Natural \&Technical Conditions & NTC & $2 \mathrm{p}$. \\
\hline 4 & Education \& Promotion & E\&P & $1 \mathrm{p}$. \\
\hline 5 & Knowledge \& Information & K\&I & $1 \mathrm{p}$. \\
\hline 6 & Good Practice & GP & $1 \mathrm{p}$. \\
\hline
\end{tabular}

\section{Action Range}

In the Action range category, 3 points have been awarded to actions or arguments directly concerning KrOF in politics, finance or natural conditions categories. Actions addressed directly to residents are more effective than actions taken at the regional level (2 points), national level (1 point) or international/EU level (1 point).

\begin{tabular}{llll}
\hline 1 & Local & LCL & $3 \mathrm{p}$. \\
\hline 2 & Regional & RGL & $2 \mathrm{p}$. \\
\hline 3 & National & NTL & $1 \mathrm{p}$. \\
\hline
\end{tabular}

\section{Action Impact}

2 points have been awarded to arguments or actions which could have a direct impact on decisions taken by laypeople towards RES. Indirect impact arguments have been awarded 1 point.

\begin{tabular}{llll}
\hline 1 & Direct & DIR & $2 \mathrm{p}$. \\
\hline 2 & Indirect & IND & $1 \mathrm{p}$. \\
\hline
\end{tabular}

Table 5. Division of factors into groups of different powers of impact according to score.

\begin{tabular}{|c|c|c|c|c|c|c|c|c|c|c|c|}
\hline \multicolumn{3}{|c|}{ Very Weak } & \multicolumn{3}{|c|}{ Weak } & \multicolumn{3}{|c|}{ Strong } & \multicolumn{3}{|c|}{ Very Strong } \\
\hline 1 & 2 & 3 & 4 & 6 & 8 & 9 & 12 & 16 & 18 & 24 & 36 \\
\hline \multicolumn{3}{|c|}{$\begin{array}{l}\text { An action or argument } \\
\text { scored } 1,2 \text { or } 3 \text { points }\end{array}$} & \multicolumn{3}{|c|}{$\begin{array}{l}\text { An action or argument } \\
\text { scored } 4,6 \text { or } 8 \text { points }\end{array}$} & \multicolumn{3}{|c|}{$\begin{array}{l}\text { An action or argument } \\
\text { scored } 9,12 \text { or } 16 \text { points }\end{array}$} & \multicolumn{3}{|c|}{$\begin{array}{l}\text { An action or argument } \\
\text { scored } 18,24 \text { or } 36 \text { points }\end{array}$} \\
\hline
\end{tabular}


For example: A publication of a report about RES would be a kind of activity in the general RES category (one point), knowledge and information subcategory (one point). Since the report is presented in a national branch magazine, this action is taken at the national level (one point). The typical layperson does not read this type of magazine, so there is a little chance that this information will reach them, thus, it does not affect their awareness or motivation for installing a RES system in the household (one point). The score of this factor is $1 \times 1 \times 1 \times 1=1$ which means that the factor is very weak.

Another example: The introduction of the Program of Reduction of Surface Emission is a very strong action. It is a local legislative regulation (policy, two points; local, three points) concerning the heating area (three points). The ban on burning solid fuels directly concerns households (two points). The final score equals $36(2 \times 3 \times 3 \times 2)$.

The range of scores possible to get has been divided into four categories (Table 5).

\subsection{Analysis}

The analysis was carried out according to the layperson perspective. The main goal was to define the strengths, weaknesses, opportunities, and threats resulting from policies and actions on different levels of governance to identify the internal and external factors that are favourable and unfavourable to the transition towards RES and elimination of harmful air pollutants in $\mathrm{KrOF}$. The results of the SWOT analysis have been shown below in four tables (Tables 6-9) representing four quarters of the SWOT matrix. For simplicity, the tables show only the selection of weaker arguments and all very strong arguments whose identification was the purpose of this analysis. 
Table 6. STRENGTHS quarter of the SWOT matrix — the full list of "very strong" factors and selected examples of "strong", "weak", and "very weak" ones.

\begin{tabular}{|c|c|c|c|c|c|c|c|c|c|c|}
\hline \multicolumn{11}{|c|}{ Strengths } \\
\hline No & Action & $\begin{array}{c}\text { RES } \\
\text { Branch }\end{array}$ & Points & $\begin{array}{c}\text { RES } \\
\text { Domain }\end{array}$ & Points & Range & Points & Impact & Points & Score \\
\hline 1 & $\begin{array}{l}\text { Due to the problem of air pollution in KrOF, the Program of Reduction of } \\
\text { Surface Emission has been introduced in the City of Krakow. Under this } \\
\text { program, since September 2019, the total prohibition on burning solid fuels, } \\
\text { including biomass, has been introduced in the City. }\end{array}$ & HTG & 3 & POL & 2 & LCL & 3 & DIR & 2 & 36 \\
\hline 2 & $\begin{array}{l}\text { Under the Regional Operational Program 2014-2020, the Krakow } \\
\text { Municipality co-finances investments related to replacement of old heating } \\
\text { boilers for installations that meet the current pollution emission standards. }\end{array}$ & HTG & 3 & FIN & 2 & LCL & 3 & DIR & 2 & 36 \\
\hline 3 & $\begin{array}{l}\text { Bank Ochrony Srodowiska (The Bank for Environmental Protection) offers } \\
\text { loans with subsidies for the purchase and installation of solar collectors for } \\
\text { households and small enterprises in the Małopolska Region. }\end{array}$ & HTG & 3 & FIN & 2 & RGL & 2 & DIR & 2 & 24 \\
\hline 4 & $\begin{array}{l}\text { Under the "Clean Air" program, the Regional Fund for Environmental } \\
\text { Protection and Water Management supports households, NGOs, local } \\
\text { government units, and business entities by co-financing investments, } \\
\text { including heat pumps and/or solar installations. }\end{array}$ & MHP & 3 & FIN & 2 & RGL & 2 & DIR & 2 & 24 \\
\hline 5 & $\begin{array}{l}\text { In 2019, the first Clean Transport Zone in Poland was introduced in the } \\
\text { Krakow district of Kazimierz. In the future, a similar limitation is expected } \\
\text { for cars with diesel engines not meeting the Euro } 5 \text { or Euro } 6 \text { standards. }\end{array}$ & EM & 2 & POL & 2 & LCL & 3 & DIR & 2 & 24 \\
\hline 6 & $\begin{array}{l}\text { In Krakow, electric cars are exempt from parking fees. The monthly } \\
\text { subscription for a hybrid car is } 2,5 \text { times lower than for other internal } \\
\text { combustion vehicles. }\end{array}$ & EM & 2 & FIN & 2 & LCL & 3 & DIR & 2 & 24 \\
\hline 7 & $\begin{array}{l}\text { The largest power plants in KrOF use cogeneration (e.g., the heat and power } \\
\text { plant in Skawina, the eco-incineration plant in Krakow and the heat and } \\
\text { power plant producing energy utilities for ArcelorMittal facilities). }\end{array}$ & MHP & 3 & POL & 2 & LCL & 3 & IND & 1 & 18 \\
\hline 8 & $\begin{array}{l}\text { Among the projects provided in the ZIT formula, the installations of RES in } \\
\text { municipal facilities and installation of a solar farm in the Wieliczka } \\
\text { Commune are planned to be built. }\end{array}$ & MHP & 3 & POL & 2 & LCL & 3 & IND & 1 & 18 \\
\hline 9 & $\begin{array}{l}\text { Krakow is the first city in Poland where bus lines operated only by electric } \\
\text { buses have been launched. Charging stations are built and it is also planned } \\
\text { to purchase electric cars for the fleet of the Municipality. }\end{array}$ & EM & 2 & POL & 2 & LCL & 3 & IND & 1 & 12 \\
\hline 10 & $\begin{array}{l}\text { In Podhale, the southern sub-region of Małopolska, the geothermal energy } \\
\text { network is implemented. This region is a model example of the substantial } \\
\text { environmental, economic and social benefits from RES. }\end{array}$ & HTG & 3 & GP & 1 & RGL & 2 & IND & 1 & 6 \\
\hline 11 & $\begin{array}{l}\text { There are a lot of branch web-portals in Poland, which collect data and } \\
\text { publish reports and information on RES development. }\end{array}$ & GR & 1 & K\&I & 1 & NTL & 1 & IND & 1 & 1 \\
\hline
\end{tabular}




\section{Comments for Table 6}

1. Due to the strong air pollution, the Program of Reduction of Surface Emission has been introduced in Krakow. This program is a system solution with legal regulations and requirements for households, combined with appropriate financial instruments, i.e., subsidies for the heat source replacement. In this case, decision-makers demonstrated consciousness that without substantial financial support, households would not be able to meet the requirements. The prohibition on burning solid fuels in heating boilers and the demand for replacing the heating systems was a turning point in the city's history. It was a very strong stimulus that triggered the transition of households towards clean energy use.

2-4. A large group of strong arguments is related to subsidies or savings due to the RES installation. Possibilities of co-financing made many households eager to take such opportunities. The economic stimulus appeared as one of the strongest that could influence clean energy investment decisions.

5,6 . The economic arguments also affect the electromobility category and hybrid cars. Electric car owners do not have to pay for parking in Krakow. In addition, in the city centre, there are special parking spaces designated only for electric cars. In such a crowded city as Krakow, easy access to a parking space is a significant benefit and could be a motivating factor for investing in an electric car.

7. This argument concerns energy production. Major power plants use combined heat and power cogeneration, and co-combustion of biomass.

8-10. These arguments are related to plans to implement RES on a local scale, e.g., RES installations to supply municipal facilities. These types of projects would directly affect air quality in urban and suburban areas but do not have a direct impact on laypeople decisions concerning household heating and power supply. However, this type of action can accelerate the motivation of local authorities and residents towards making a joint effort to improve air quality. 
Table 7. WEAKNESSES quarter of the SWOT matrix—the full list of "very strong" factors and selected examples of "strong", "weak", and "very weak" ones.

\begin{tabular}{|c|c|c|c|c|c|c|c|c|c|c|}
\hline \multicolumn{11}{|c|}{ Weaknesses } \\
\hline No & Action & $\begin{array}{c}\text { RES } \\
\text { Branch }\end{array}$ & Points & $\begin{array}{c}\text { RES } \\
\text { Domain }\end{array}$ & Points & Range & Points & Impact & Points & Scor \\
\hline 1 & $\begin{array}{l}\text { The Program of Reduction of Surface Emission in Krakow does not directly } \\
\text { promote the use of RES (as it allows the use of gas and light oil boilers) nor the } \\
\text { thermal modernisation of houses. }\end{array}$ & HTG & 3 & POL & 2 & LCL & 3 & DIR & 2 & 36 \\
\hline 2 & $\begin{array}{l}\text { Paradoxically, the prohibition on solid fuels combustion can contribute to downturn } \\
\text { in the transition towards RES, and particularly biomass, in household installations. } \\
\text { However, such a ban had to be introduced because wood, pellets, and briquettes } \\
\text { burned in installations without filters largely contribute to the PM emission. }\end{array}$ & HTG & 3 & POL & 2 & LCL & 3 & DIR & 2 & 36 \\
\hline 3 & $\begin{array}{l}\text { Cars fuelled with fossil fuels will remain the basic mobility option for a long time. } \\
\text { It is because of the high costs of purchasing an electric car. The use of cars will } \\
\text { remain the basic mobility option in less urbanised areas of KrOF where housing } \\
\text { dispersion unbales public transport to cover the mobility needs. }\end{array}$ & EM & 2 & FIN & 2 & LCL & 3 & DIR & 2 & 24 \\
\hline 4 & $\begin{array}{l}\text { Krakow is one of the most traffic-jammed cities in Poland. The main reason is the } \\
\text { dysfunctional city development model based on the development of single-use } \\
\text { zones and the chaotic development of dispersed households on the suburbs. These } \\
\text { factors increase the dependence on individual transport. }\end{array}$ & EM & 2 & POL & 2 & LCL & 3 & DIR & 2 & 24 \\
\hline 5 & $\begin{array}{l}\text { Bicycles and electric motorcycles could become an alternative to cars in areas } \\
\text { outside the cities but the climatic conditions in Poland (changing temperatures and } \\
\text { rains) are barriers for popularisation of two-wheelers. }\end{array}$ & EM & 2 & NTC & 2 & LCL & 3 & DIR & 2 & 24 \\
\hline 6 & $\begin{array}{l}\text { Solar farms and wind farms need large areas for industrial electricity production. } \\
\text { This could cause difficulties in implementing this type of RES in KrOF because of } \\
\text { the dispersion of housing, a large percentage of forests and nature protection areas, } \\
\text { as well as the growing demand for recreational areas in Krakow and } \\
\text { surrounding unicipalities. }\end{array}$ & $\mathrm{PW}$ & 3 & POL & 2 & LCL & 3 & IND & 1 & 18 \\
\hline 7 & $\begin{array}{l}\text { Some of the RES investments cause protests in local communities. The main } \\
\text { sources of information in conflict situations are local media and branch } \\
\text { media-often representing the two opposed poles of public opinion. There is an } \\
\text { inadequacy of education, communication instruments, and experience in integrated } \\
\text { urban management involving a participatory approach for prevention and } \\
\text { mitigation of conflicts. }\end{array}$ & PW & 3 & $E \& P$ & 1 & LCL & 3 & IND & 1 & 9 \\
\hline 8 & $\begin{array}{l}\text { In Poland, a significant part of RES generation installed capacity is based on } \\
\text { unstable energy sources (wind, sun, some of hydro) and makes it necessary to } \\
\text { maintain reserve capacity and a high flexibility of the national energy system based } \\
\text { on conventional fuels. }\end{array}$ & PW & 3 & POL & 2 & NTL & 1 & IND & 1 & 6 \\
\hline 9 & $\begin{array}{l}\text { Scientific research and some activities focusing on RES development not keep up } \\
\text { with the dynamics of changes in the branch. Together with the inadequacy of a RES } \\
\text { monitoring system, it causes that many studies present the outdated state of affairs. }\end{array}$ & GR & 1 & K\&I & 1 & NTL & 1 & IND & 1 & 1 \\
\hline
\end{tabular}




\section{Comments for Table 7}

While the Program of Reduction of Surface Emission in Krakow is a very strong argument in the Strengths quarter of the SWOT matrix, it is also one of the leading ones among weaknesses. On the one hand, the Program imposes a total prohibition on burning solid fuels and strongly supports the change of a heat source. On the other hand, RES is not directly promoted in this program. In effect, the most popular heat source replacement option is low-emission gas boilers. Households that have invested in such a source of heat, will not take any initiatives towards RES for many years to come. The program was the chance for the popularization of RES but did not use that opportunity.

The paradox of prohibition on burning solid fuels in households is a decrease in the share of the use of RES in home installations. It is because the biomass (wood, pellets, and briquettes) was a very popular source of energy for heating homes and now it is banned. From the RES development point of view, this needs to be regarded as a weakness, although it has been a very important regulation for the reduction of PM emission because the combustion of biomass in installations without filters contributes to the emission of particulate matter.

4, 5. These strong factors are related to electromobility and linked with politics and finance. The spatial planning policy based on the monofunctional economic zones, service and retail centres, and single-use housing estates—often dispersed-makes residents dependent on individual transport. Some of the implemented benefits form electromobility seem insignificant because for many people the city centre is not the destination but a transit route. The collective dependence on individual transport, together with the high cost of electric vehicles, cause that households are not switching from fossil-fuelled cars to clean urban mobility options on a significant scale.

6. This factor does not directly address layman but remains important. The difficulty with building large scale RES installations in the metropolitan area is related to spatial planning priorities. Krakow needs more and more space for housing and green natural and recreational areas. The city advantage is a large acreage of protected areas due to valuable natural conditions. They take up space that could be otherwise used for RES installations. 
Table 8. OPPORTUNITIES quarter of the SWOT matrix—the full list of "very strong" factors and selected examples of "strong", "weak", and "very weak" ones.

\begin{tabular}{|c|c|c|c|c|c|c|c|c|c|c|}
\hline \multicolumn{11}{|c|}{ Opportunities } \\
\hline No & Action & $\begin{array}{c}\text { RES } \\
\text { Branch }\end{array}$ & Points & $\begin{array}{c}\text { RES } \\
\text { Domain }\end{array}$ & Points & Range & Points & Impact & Points & Score \\
\hline 1 & $\begin{array}{l}\text { In KrOF, there are good conditions for the further development of biogas } \\
\text { plants using fermentation processes from organic waste at landfills } \\
\text { (including the Barycz landfill in Krakow), animal waste on farms, and } \\
\text { sewage sludge in sewage treatment plants. }\end{array}$ & MHP & 3 & NTC & 2 & LCL & 3 & IND & 1 & 18 \\
\hline 2 & $\begin{array}{l}\text { RES technologies dominating in KrOF are based on multi-fuel combustion } \\
\text { (with biomass) and thermal waste treatment. On one hand, this allows } \\
\text { covering the increasing demand for heat and electricity production. On the } \\
\text { other hand, this helps to manage the increasing amount of waste in Krakow } \\
\text { and the neighbouring communes. }\end{array}$ & MHP & 3 & NTC & 2 & LCL & 3 & IND & 1 & 18 \\
\hline 3 & $\begin{array}{l}\text { Major KrOF urban areas produce large amounts of sewage and waste and } \\
\text { that ensures supplies for biogas production. Access to this stock is also } \\
\text { important for the operation of the thermal waste treatment plant in Krakow. }\end{array}$ & PW & 3 & NTC & 2 & LCL & 3 & IND & 1 & 18 \\
\hline 4 & $\begin{array}{l}\text { One of the priorities of Integrated Territorial Investment (ITI) in KrOF, is the } \\
\text { transition to a low-carbon economy, implemented through energy } \\
\text { modernisation of public and private facilities, smart energy management, } \\
\text { and implementation of RES. }\end{array}$ & MHP & 3 & POL & 2 & LCL & 3 & IND & 1 & 18 \\
\hline 5 & $\begin{array}{l}\text { In the KrOF area, the air pollution is the major problem. In the ITI Strategy } \\
\text { for KrOF it is noted that the low quality of air is the factor that should } \\
\text { mobilise Metropolia Krakowska Association towards supporting } \\
\text { investments in RES application. }\end{array}$ & GR & 3 & POL & 2 & LCL & 3 & IND & 1 & 18 \\
\hline 6 & $\begin{array}{l}\text { In the Development Strategy of the Region, it is postulated to treat the } \\
\text { energy transformation for air quality improvement as a priority. The key } \\
\text { would be the increase of RES use and the improvement of energy } \\
\text { management in Małopolska. }\end{array}$ & PW & 3 & POL & 2 & RGL & 2 & IND & 1 & 12 \\
\hline 7 & $\begin{array}{l}\text { Some of the Polish heating companies possess large undeveloped areas } \\
\text { which could be used for building solar farms. }\end{array}$ & PW & 3 & NTC & 2 & NTL & 1 & IND & 1 & 6 \\
\hline 8 & $\begin{array}{l}\text { There is a number of strong arguments that can encourage society to accept } \\
\text { investments in RES (health protection, reduction of electricity prices, } \\
\text { environmental cleanliness, reduction of air pollution, technological } \\
\text { progress, new jobs, energy security, income for the municipality and } \\
\text { residents). Open discourse and education are necessary to transfer these } \\
\text { arguments to society; however, they need to be considered together with } \\
\text { other measures. The attitude does not directly affect the decisions of } \\
\text { households to make the transition to RES. }\end{array}$ & GR & 1 & $\mathrm{E} \& \mathrm{P}$ & 1 & NTL & 1 & IND & 1 & 1 \\
\hline
\end{tabular}




\section{Comments for Table 8}

The classic approach to SWOT assumes that opportunities and threats relate to the external environment. However, in the non-business approach — that is used in this study-one can relate opportunities and threats to the future, as opposed to strengths and weaknesses that relate to the present.

1-3. In the group of strong factors defined in SWOT as opportunities, there are those related to natural, urban, and rural conditions, such as availability of organic matter, agricultural waste, or sewage sludge that could be used as a raw material in biogas plants. Krakow, as a large urban centre, has and will have a continues flow of significant quantities of waste organic matter. A similar situation is related to non-recyclable urban waste utilised in thermal waste treatment processes.

4. One of the signs of the transition to a low carbon economy is the thermal modernisation of public facilities.

5. Highly rated opportunities are connected with air quality policies and subsidy programmes that affect the attitude towards low-emission economy and support the investors financially.

6. The transition of the energy sector of the industry contributes to the improvement of air quality but is not significant for the transition of households to RES.

8. Education and availability of information change the layman's attitude towards RES. However important as a supporting factor, such an attitude does not directly affect the decisions of households about making the transition to RES. The analysis shows that the majority of households have not made the investment decisions until the legal regulations were imposed and/or substantial subsidies were secured. 
Table 9. THREATS quarter of the SWOT matrix—the full list of "very strong" factors and selected examples of "strong", "weak", and "very weak" ones.

\begin{tabular}{|c|c|c|c|c|c|c|c|c|c|c|}
\hline \multicolumn{11}{|c|}{ Threats } \\
\hline No & Action & $\begin{array}{c}\text { RES } \\
\text { Branch }\end{array}$ & Points & $\begin{array}{c}\text { RES } \\
\text { Domain }\end{array}$ & Points & Range & Points & Impact & Points & Score \\
\hline 1 & $\begin{array}{l}\text { Social factors in RES investments include tensions related to the distribution } \\
\text { of benefits from these investments. When external investments are } \\
\text { regarded, a small group of investors and chosen landowners would increase } \\
\text { their income substantially, while their neighbours may feel only to bear the } \\
\text { costs associated with changes in the landscape. }\end{array}$ & PW & 3 & FIN & 2 & LCL & 3 & DIR & 3 & 24 \\
\hline 2 & $\begin{array}{l}\text { In smaller towns, there would be more opportunities for modernisation of } \\
\text { the heating grid due to shorter sections of the grid and a lower number of } \\
\text { facilities that need to be thermally modernised. However, in such towns } \\
\text { heat is provided by communal units that often do not have resources to } \\
\text { finance this type of projects. The external sources of financing such big } \\
\text { projects may be needed. }\end{array}$ & HTG & 3 & NTC & 2 & LCL & 3 & IND & 1 & 18 \\
\hline 3 & $\begin{array}{l}\text { The low level of ecological awareness and lack of knowledge about the } \\
\text { energy sources and systems may cause protests against plans or projects } \\
\text { related to energy system transition. Communities tend to protest when a } \\
\text { specific plan of the location of a new installation in their neighbourhood } \\
\text { appears without the participation of the society. }\end{array}$ & GR & 1 & K\&I & 1 & LCL & 3 & DIR & 3 & 9 \\
\hline 4 & $\begin{array}{l}\text { As a result of the development of prosumer energy installations, problems } \\
\text { can appear in the management of the existing energy grid. In Poland, } \\
\text { energy distribution grids are not sufficiently adapted to two-way operation } \\
\text { on a large scale. Grid adaption for new conditions will be very expensive. }\end{array}$ & PW & 3 & NTC & 2 & NTL & 1 & IND & 1 & 6 \\
\hline 5 & $\begin{array}{l}\text { Opinion polls indicate a lack of public awareness about types of RES } \\
\text { installations, prosumer investment mechanisms, and the expected payback } \\
\text { time. }\end{array}$ & MHP & 3 & K\&I & 1 & NTL & 1 & IND & 1 & 3 \\
\hline
\end{tabular}




\section{Comments for Table 9}

1,3. Economic benefits and savings are among the main factors motivating households to change the heating system and source of electricity. On the other hand, the presumption that only a few neighbours could achieve significant financial benefits by renting land for the RES installation such as wind turbines, that will affect the quality of life in the area, could be a driving force for protests against such investments. Such protests are not common but when they occur, they can directly affect investments especially in rural and suburban areas.

$2,4,5$. A serious barrier to the development of larger RES installations is the costs of development of heating networks, particularly in smaller towns and suburban areas. Network solutions could be effective alternatives for dispersed heating sources, but they need substantial investments. For local governments and commercial companies in the energy industry, the expansion of such networks is not perceived as a profitable investment. That is the main reason why the transition towards clean heating systems is to a large extent dependent on the decisions of laypeople.

\section{Results}

The European Union, and Poland as its part, are in the process of transition towards the low-carbon economy. The application of RES is increasing and their positive impact on the environment is known, but the scale of its impact is difficult to measure.

This article draws from the authors' analysis of the use of RES as a means for reducing harmful emissions in KrOF. For this purpose, the inventories of renewable energy sources and systems were compiled as a part of the EU project "Smart Edge - Sustainable Metropolitan Areas and the Role of The Edge City". Using the data from the inventories, a SWOT analysis has been carried out to identify factors that determine the development of RES and smart management of their potential.

Special emphasis was placed on the transition towards RES by households which are known as the main source of pollutants including the most locally harmful PM and B(a)P (Figure 2) [8] (p. 34). Since the core City of Krakow largely eliminated this type of emission within its own territory thanks to a complete ban on solid fuels combustion in household installations, the problem remains valid in the 14 independent communes surrounding the city and affecting the whole metropolitan area. Their transition to low-emission energy sources is dependent on both economic and cultural conditions and individual decisions of residents. Thus, the SWOT assessment was carried out through the criterion of the layperson point of view. The main goal was to find and name factors that could determine the decisions of households to make the transition from traditional to low-emission and renewable sources of energy.

The results of the analysis have shown that many actions have been taken at the national, regional and local levels but the greatest impact on household decisions have the ones initiated and implemented at the communal level. The conclusion is that legal regulations should be combined with education and tailor-made financial instruments and local incentives. The proposed method can be applied in other metropolitan areas as a diagnostic procedure and support for future action planning to solve air-quality problems caused by distributed emission sources.

We found the qualitative analysis particularly useful in the context of insufficient quantitative information about the distributed sources of energy and irregularity of various financial instruments. However, the situation in $\mathrm{KrOF}$ is very dynamic and the quantitative data is increasingly accessible. Thus, it is planned to extend this study in the nearest future to include quantitative and cross-SWOT analysis. They will be presented in the next paper, which is to be provided as a continuation of this article.

\section{Discussion}

The inventories performed by the authors [31,32] show that a lot has been done so far to solve the problem of heavy air pollution in $\mathrm{KrOF}$. As regards the effects of those actions, according to the 
data from the Regional Inspectorate for Environmental Protection [9] during the decade of 2007-2017 a substantial reduction of pollutants has been achieved:

- dust emissions have decreased by $72 \%$;

- gaseous pollutants (excluding $\mathrm{CO}_{2}$ ) have been reduced by $53 \%$;

- $\mathrm{CO}_{2}$ emissions have decreased by $29 \%$.

RES play an increasingly important role in energy transition and climate change mitigation as the means to fight environmental pollution. For this reason, the development of RES is one of the priority areas in global policies, including Sustainable Development Goals (SDG). It is also an important direction of the EU energy and climate policy which was reflected in the directive on the promotion of the use of energy from renewable sources [12]. Pursuant to the directive, the National Renewable Energy Action Plan 2020 (KPD) [20] defines the targets and the measures to be taken to increase the share of renewable energy in the use of final energy. KPD also lists support systems for the promotion of the use of energy from renewable sources and defines the principles of cooperation between local, regional, and national authorities to increase the use of renewable energy (EP 2010/31/UE).

Another fundamental document that is to ensure energy security, as well as economical and rational management of fuels and energy, is the Energy Act [39]. It defines, among other things, the most important tasks of the local government in the field of energy, including planning and organisation of activities aimed at rationalising energy consumption and the promotion of solutions reducing energy consumption in the commune. These tasks may be carried out by the local government by developing and implementing e.g., a spatial strategy (the study of the conditions and directions of the commune's spatial development), local spatial plans, an appropriate air protection program, or air quality plan (AQP/POP) and assumptions for the plan for heat, electricity, and gas supply.

The current assumptions for the development of renewable energy in Poland are set out in the Renewable Energy Sources Act [40]. The act defines the terms and conditions for the production of energy from renewable sources, as well as mechanisms and instruments for supporting RES. From the point of view of this paper, the provisions concerning prosumer energy are of fundamental importance. In the recent amendments of the RES Act, the catalogue of entities that may benefit from incentives to prosumer investments has been expanded beyond natural persons to include, among others, public sector institutions and entrepreneurs. In the new version of the RES Act, the energy cooperatives which generate electricity for their and their members' purposes were also included in the prosumer catalogue. Among the solutions of the RES Act, there is a simplified procedure for reporting prosumer installations and principles of settling with grid operators.

According to the Energy Policy of Poland 2030 [41], the main goal of developing RES is reducing emissions from the energy sector and diversification of the structure of energy production. The legislation at the national level makes Poland ready to implement the solutions to meet the goals set by the UE regulations. However, it will be local governments that bear the greatest responsibility to implement specific actions that will contribute to the development of RES and reduce the environmental costs of burning conventional fuels in households and in the transport. Local governments are closest to the citizen, and their policies, programs, projects, and practices could drive residents to take steps towards RES.

The Draft PEP2040 (as of 2019-11-04) contains provisions for the role of local governments in the implementation of specific objectives, i.e., ensuring conditions for the development of energy-sustainable areas at the local level (energy clusters and cooperatives-target: Approximately 300 in 2030). The involvement of local governments and local energy planning will have a special role in the implementation of the National Heating (and Cooling) Plan. It is planned to activate communes, poviats, and regions in energy planning resulting in rational energy management, the development of clean energy sources, and the improvement of air quality. Planning should be based on real cooperation between regional and local authorities with respect to their specific competences: 
- The regional government participates in the planning of energy and fuel supply and examines the compliance of energy plans with the national energy policy.

- Poviats are responsible for system security, public services, and citizens' security. This obligation is extremely important in dispersed generation systems.

- Regional and local authorities are responsible for providing conditions for the development of clean and efficient heating systems. They are obliged to cooperate with the minister responsible for energy matters and the voivode in the planning and implementation of fuel and energy supply systems.

- Municipalities are responsible for planning and organising the supply of heat and electricity in the commune; the rationalisation of energy consumption; the promotion of consumption reducing solutions; and the assessment of the potential of local electricity generation.

- Municipalities and bottom-up local initiatives play a crucial role in building awareness and ecological needs, thus the combined sales, as well as various forms of financial support from public funds are to be used as incentives for using RES.

The good practices presented in the Section 2.2 proof the effectiveness of local policies and actions developed by municipalities and NGOs in KrOF. The residents are increasingly aware of the influence of air quality to their health and quality of life, and increasingly active in demanding proper solutions.

The report presented by the Pro-Akademia R\&I Centre [42] indicates a high level of acceptance of investments in energy efficiency measures among municipal authorities. There is also a growing number of arguments to convince the public to accept such investments (cleanliness, environmental and health benefits, reduction of energy prices, technological progress, new jobs, energy security, and income for the commune and residents). However, the promotion of RES knowledge should be increased to provide municipalities with comprehensive data. There is not enough awareness of, e.g., differences between fuels regarding $\mathrm{CO}_{2}$ and PM emissions. Quite often, biomass is treated as a clean fuel even if, when incinerated in installations without filters, it contributes to high PM emissions. It is important that the thermal modernisation campaign promotes the replacement of old boilers with truly clean energy installations, such as hybrids of PV and heat pumps.

Thus, a wider information campaign promoting the reduction of energy demand for buildings should be launched. Regarding all new buildings and the thermal modernisations subsidised by a government, the obligation to use clean and renewable energy sources might be needed.

\subsection{Monitoring and Evaluation}

In the Environmental Impact Assessment for the Territorial Investment Strategy for KrOF [43], the following indicators were proposed related to RES:

- the power of devices using energy from RES, as part of projects implemented in KrOF;

- electricity consumption per capita in KrOF;

- a number of new installations using RES in municipal facilities, as part of projects implemented in $\mathrm{KrOF}$.

However, this type of monitoring has not been implemented so far, even if control of the effectiveness of implemented projects seems to be the fundamental factor determining the further development of distributed RES.

The monitoring activities are concentrated on the influence of regional and local policies on air quality. In 2016-2020, the Regional Inspectorate for Environmental Protection in Krakow (RIEP) have been conducting measurements of $\mathrm{PM}_{10}, \mathrm{PM}_{2.5}, \mathrm{SO}_{2}, \mathrm{NO}_{2}, \mathrm{NO}, \mathrm{NO}_{\mathrm{x}}, \mathrm{O}_{3}$, benzene, $\mathrm{CO}_{\mathrm{x}}$, as well as $\mathrm{Pb}, \mathrm{As}, \mathrm{Cd}, \mathrm{Ni}$, and $\mathrm{B}(\mathrm{a}) \mathrm{P}$ concentrations in $\mathrm{PM}_{10}$ dust, in accordance with methodologies set out in the Regulation of the Minister of the Environment regarding the assessment of air substance levels [44]. The measurement plan includes 27 stations. These measurements are carried out continuously (automatic measurement), systematically (manual measurement), and periodically (mobile station—automatic and manual measurement) [45]. 
Test results and annual air quality assessments are used by the Małopolska Regional Assembly to update air protection programmes. RIEP, as part of the Air Quality Monitoring System in Małopolska, publishes on a regular basis the measurement results, transmitted directly from the measuring stations, on an interactive map [46].

The regional and local authorities, as well as the RIEP, the Krakow Metropolis Association, and some of the municipalities, also cooperate with the Polish Smog Alarm (PAS)—a non-governmental organization, thanks to which the topic of air pollution has been permanently present in public debate in recent years. PAS conducts and publishes its own air quality tests using portable dust meters [47].

What is of growing importance, as part of the protective actions specified in the Air Quality Plans (AQPs/POPs), the mayors are responsible for controlling home furnaces with respect to compliance with the ban on waste incineration and, in the case of Krakow, also the ban of burning solid fuels.

Regarding the monitoring or assessment of benefits used by the municipalities in relation to investment and subsidy programmes, currently used monitoring tools, e.g., in Skawina, are based on testing the efficiency of completed installations, such as PV panels. Other benefits from the implementation of investments in improving the energy efficiency of buildings are not monitored, their effectiveness is determined based on design assumptions. Acquiring data from individual buildings, especially single-family ones, is time-consuming and inefficient, while the monitoring of the impact of investments in public buildings-according to the officers themselves-comes to the background because of the tight schedules of the municipal offices. Therefore, incentives are needed for municipalities to make an effort to monitor the environmental, social, and economic benefits of improving the energy efficiency of buildings.

\subsection{Planning Conditions}

The RES technologies which dominate in KrOF are based on biogas, multi-fuel combustion (with biomass), and thermal waste treatment. These types of fuels allow also for covering the increasing future demand for heat and electricity production in $\mathrm{KrOF}$ and additionally will help to manage and utilise the increasing amount of sewage and waste in Krakow and in the neighbouring municipalities.

The review of documents analysing conditions for the RES development in KrOF [32] provides information on the obstacles to achieving a large scale of industrial energy production from other types RES, as follows:

- $\quad$ PV Effective localisation of photovoltaic farms requires non-shadow places and a dust-free area. It is also necessary to find a sufficiently large, flat area. The levels of urbanisation and air pollution in KrOF make them less profitable.

- Wind farms The location of a wind farm must have a stable wind regime. Distances from the households, transport infrastructure, electricity networks, agricultural areas, nature protection areas, and environmental conditions-areas of nesting and migration routes of birds and bats-make the metropolitan area of Krakow unfavourable for building of large wind turbines.

- Hydroelectricity Hydroelectric power plants have been built mainly in the areas with great land slopes or in places where the water was dammed up. There is no potential in $\mathrm{KrOF}$ to develop that kind of plants.

- Geothermal sources The main qualifying factors for geothermal heat or electricity production are specification of geothermal waters (e.g., temperature, mineralisation), geological conditions (e.g., aquifer depth and its extension), and the heat customer structure and spatial distribution. A dispersed type of urbanisation which dominates in $\mathrm{KrOF}$ towns and villages can cause unfavourable economic and technical conditions for big-scale heat production from geothermy, even if the geothermal water parameters and other natural conditions are met.

Due to the natural and urban conditions, there is no much space available in the City of Krakow for low-carbon/low-emission RES installations to grow on an industrial scale. The distributed prosumerism—small PV installations and small wind turbines combined with heat pumps—is the only 
way to increase the share of low-emission RES in the nearest future. In the KrOF communes around Krakow, due to the dominating pattern of dispersed housing, the prosumer energy development is also regarded as the most probable direction of renewable energy installations to grow.

\section{Conclusions}

For the sustainable increase of RES capacity and its substantial contribution to low-emission energy sources and the reduction of air pollutants, it is necessary for the municipalities to interact directly with both community and city infrastructure, and to monitor what is happening in the metropolitan area and how it is evolving. Combining top-down and bottom-up approaches, the smart solutions might enhance the quality, performance, and interactivity of urban management including the smart management of the transition to RES. In KrOF, the grassroots NGOs have been playing a pivotal role in the activation of communities and education of various stakeholders whilst the local governments joined in creating institutional and financial conditions for low-emission projects.

Although much remains to be done, the effects of investing in RES to date are promising. Since the research indicates a low potential for the development of low-carbon RES on an industrial scale, efforts must be directed primarily at promoting networked distributed energy solutions.

The inventories and analysis of local good practices show that significant efforts devoted by the EU to devising strategies and financial support for achieving smart urban growth for its metropolitan cities and regions bring substantial effects. The EU contribution in the forms of legislative solutions and incentive programmes were of fundamental importance for the development of RES in Poland and particularly in $\mathrm{KrOF}$ which became a source of lighthouse projects for other metropolitan areas in Poland struggling with air pollution.

The SWOT analysis has shown that for the popularisation of RES, a number of instruments need to be provided simultaneously, including legislative instruments imposing local restrictions on the use of certain fuels and financial instruments in the form of incentives to invest in RES. Educational actions and media play an important role too, in the popularisation of environmentally friendly solutions as bringing not only health improvement but also long-term economic benefits. However, without the proper legislation and incentive programmes the change of attitude is not a sufficient factor. Only local policies directed in an integrated way at the simultaneous application of various instruments can bring effects appropriate to the scale of challenges that the KrOF municipalities are still facing.

Another important factor would be the network cooperation between urban, suburban, and rural areas of KrOF initiated by Krakow Metropolis Association. The Smart Metropolis potential of integrated management may concern various dimensions of development such as food security, employment, investment, as well as climate change adaptation and mitigation. In the case of KrOF, it was decided by the members of KMA that the smart, integrated solutions would be implemented first in the fields related to the air quality as the most urgent, that is: The environment, transportation, energy efficiency, and energy acquisition.

The smart metropolitan city by definition cannot develop in isolation but the application of smart city urbanism in peripheral urban areas seems to be an under-researched dimension. The cooperation between the metropolitan city and the neighbouring communes is particularly important when the air quality is regarded. The rural communities in the metropolitan area to the same extent as the metropolitan city require the improvement of social, technical, utility, and governance infrastructure, to strengthen the integration of environmental policy, stimulate the green economy and quality of life with the activation of new approaches of thinking, acting, and cooperation in the metropolitan ecosystem.

Author Contributions: Conceptualisation, T.J.; Investigation, T.J. and M.D.; Methodology, M.D.; Supervision, T.J.; Validation, B.T. and L.P.; Writing—original draft, T.J. and M.D.; Writing—review \& editing, T.J. All authors have read and agreed to the published version of the manuscript.

Funding: This paper has been partly financed from AGH-UST project No 16.16.140.315 and budgetary resources of CUT. 
Conflicts of Interest: The authors declare no conflict of interest.

\section{References}

1. WHO. Ambient (Outdoor) Air Pollution. Available online: https://www.who.int/en/news-room/fact-sheets/ detail/ambient-(outdoor)-air-quality-and-health (accessed on 20 February 2020).

2. European Environment Agency. Air Quality in Europe-2018 Report; EEA Report No. 12/2018; European Environment Agency: Copenhagen, Denmark, 2018; ISBN 978-92-9213-989-6.

3. Kaczmarczyk, M.; Sowiżdżał, A.; Tomaszewska, B. Energetic and Environmental Aspects of Individual Heat Generation for Sustainable Development at a Local Scale-A Case Study from Poland. Energies 2020, 13, 454. [CrossRef]

4. Krakowski Alarm Smogowy. Available online: https://krakowskialarmsmogowy.pl/text/dopobrania (accessed on 20 February 2020).

5. Noorollahi, Y.; Itoi, R.; Yousefi, H.; Mohammadi, M.; Farhadi, A. Modeling for diversifying electricity supply by maximizing renewable energy use in Ebino city southern Japan. Sustain. Cities Soc. 2017, 34, 371-384. [CrossRef]

6. Dahala, K.; Juhola, S.; Niemelä, J. The role of renewable energy policies for carbon neutrality in Helsinki Metropolitan area. Sustain. Cities Soc. 2018, 40, 222-232. [CrossRef]

7. De Luca, G.; Fabozzi, S.; Massarotti, N.; Vanoli, L. A renewable energy system for a nearly zero greenhouse city: Case study of a small city in southern Italy. Energy 2018, 143, 347-362. [CrossRef]

8. Program Ochrony Powietrza dla Województwa Małopolskiego. Uchwała Nr XXXII/451/17 Sejmiku Województwa Małopolskiego z dnia 23 stycznia 2017 r; BIP Województwa Małopolskiego: Kraków, Poland, 2017.

9. Wojewódzki Inspektorat Ochrony Środowiska w Krakowie/Regional Inspectorate for Environmental Protection in Krakow. Raport o Stanie Środowiska Województwa Małopolskiego w 2017 roku; BMŚ: Kraków, Poland, 2018.

10. Development Strategy of the Małopolska Region for 2011-2020. Annex no. 1 to the Resolution No. XII/183/11 of the Regional Assembly of the Matopolska Region of 26 September 2011; The Marshal Office of the Małopolska Region: Kraków, Poland, 2011.

11. The Małopolska Region Spatial Development Plan. Resolution No. XLVII/732/18 of the Regional Assembly of the Małopolska Region of 26 March 2018; The Marshal Office of the Małopolska Region: Kraków, Poland, 2018.

12. Directive 2009/28/EC of the European Parliament and of the Council of 23 April 2009 on the Promotion of the use of energy from renewable sources. Off. J. Eur. Union 2009, 5, 6.

13. Noworól, A. Strategia Zintegrowanych Inwestycji Terytorialnych dla Krakowskiego Obszaru Funkcjonalnego/The Integrated Territorial Investment [ZIT] Strategy of KrOF; Aleksander Noworól Konsulting: Kraków, Poland, 2014.

14. Uchwała nr CXXI/1918/14 Rady Miasta Krakowa z dnia 5 listopada 2014 r. w sprawie przyjęcia Programu Ograniczania Niskiej Emisji dla Miasta Krakowa; BIP: Kraków, Poland, 2014.

15. Energy Regulatory Office. Register of Energy and Heat Production Companies with a License Other than for Liquid Fuels. Available online: https://rejestry.ure.gov.pl/ (accessed on 20 June 2019).

16. Chmielewski, A.; Gumiński, R.; Mączak, J.; Radkowski, S.; Szulim, P. Aspects of balanced development of RES and distributed micro-cogeneration use in Poland: Case study of a $\mu \mathrm{CHP}$ with Stirling engine. Renew. Sustain. Energy Rev. 2016, 60, 930-952. [CrossRef]

17. Colmenar-Santosa, A.; Rosales-Asensioa, E.; Borge-Diezab, D.; Blanes-Peirób, J.J. District heating and cogeneration in the EU-28: Current situation, potential and proposed energy strategy for its generalization. Renew. Sustain. Energy Rev. 2016, 62, 621-639. [CrossRef]

18. Raj, N.T.; Iniyan, S.; Goic, R. A review of renewable energy based cogeneration technologies. Renew. Sustain. Energy Rev. 2011, 15, 3640-3648. [CrossRef]

19. Isa, N.M.; Tan, C.W.; Yatim, A.H.M. A comprehensive review of cogeneration system in a microgrid: A perspective from architecture and operating system. Renew. Sustain. Energy Rev. 2018, 81, 2236-2263. [CrossRef]

20. Krajowy Plan Działania w Zakresie Energii ze Źródeł Odnawialnych; Ministerstwo Gospodarki: Warszawa, Poland, 2010.

21. Directive 2010/31/EU of the European Parliament and of the Council of 19 May 2010 on the energy performance of buildings. Off. J. Eur. Union 2010, 18, 6. 
22. Ministerstwo Aktywów Państwowych. Krajowy plan na rzecz energii $i$ klimatu na lata 2021-2030/National Energy and Climate Plan for the years 2021-2030; MAP: Warszawa, Poland, 2019.

23. Forum Energii. Poland's Energy and Climate Plan to 2030-Not Sufficient EU Perspective. Available online: https://forum-energii.eu/en/blog/uwagi-kpeik (accessed on 20 February 2020).

24. Uchwała nr 1612/19 Zarządu Województwa Małopolskiego z dnia 29 Sierpnia 2019 r. w Sprawie Przyjęcia Projektu Strategii Rozwoju Województwa Małopolska 2030; BIP Województwa Małopolskiego: Kraków, Poland, 2019.

25. Caragliu, A.; Del Bo, C.; Nijkamp, P. Smart cities in Europe. J. Urban Technol. 2011, 18, 2. [CrossRef]

26. Allam, Z.; Newman, P. Redefining the smart city: Culture, metabolism and governance. Smart Cities 2018, 1, 4-25. [CrossRef]

27. Allam, Z.; Tegally, H.; Thondoo, M. Redefining the use of big data in urban health for increased liveability in smart cities. Smart Cities 2019, 2, 259-268. [CrossRef]

28. Yigitcanlar, T.; Han, H.; Kamruzzaman, M. Approaches, advances, and applications in the sustainable development of smart cities: A commentary from the guest editors. Energies 2019, 12, 4554. [CrossRef]

29. Allam, Z. Sustainability and resilience in megacities through energy diversification, land fragmentation and fiscal mechanisms. Sustain. Cities Soc. 2020, 53, 101841. [CrossRef]

30. KMA. Plan Likwidacji kotłów węglowych w Metropolii Krakowskiej do 2022 Roku, Załącznik do Uchwały nr 20/IV/2018 Nadzwyczajnego Walnego Zebrania Członków Stowarzyszenia Metropolia Krakowska z dnia 11 października 2018 r. Kraków 2018. Available online: http://metropoliakrakowska.pl/wp-content/uploads/ 2019/10/Plan-likwidacji-kot\T1\lów_podpisany-11.10.2018-1.pdf (accessed on 20 February 2020).

31. Jeleński, T. Renewable Energy and Energy Systems in Buildings; Inventory for Krakow Metropolis Association: Kraków, Poland, 2020.

32. Jeleński, T.; Dendys, M. Economic Development on the Basis of Renewable Energies; Inventory for Krakow Metropolis Association: Kraków, Poland, 2019.

33. Jeleński, T. Participatory Urban Planning: Metropolia Krakowska Current Local Practice; Inventory for Krakow Metropolis Association: Kraków, Poland, 2019.

34. Uchwała Nr XI/144/19 Rady Miejskiej W Skawinie z dnia 28 Sierpnia 2019 r. w Sprawie Przyjęcia Regulaminu Realizacji Przedsięwzięć Niskoemisyjnych Budynków Jednorodzinnych w Ramach Programu STOP SMOG Oraz Sposobu i Warunków Wnoszenia Wkładu Własnego; Dziennik Urzędowy Województwa Małopolskiego z 4 września 2019, poz. 6211; INFOR: Skawina, Poland, 2019.

35. Niepołomice.eu. Ekopartnerzy na Rzecz Słonecznej Energii Małopolski. Available online: https://www. niepolomice.eu/ogloszenia/ekopartnerzy-na-rzecz-slonecznej-energii-malopolski/ (accessed on 20 February 2020).

36. Cire.pl. PGE Energia Ciepła Wspiera Kraków w Monitorowaniu Zużycia Mediów w Budynkach Użyteczności Publicznej. Available online: https://www.cire.pl/item,179596,8,0,0,0,0,0,pge-energia-cieplawspiera-krakow-w-monitorowaniu-zuzycia-mediow-w-budynkach-uzytecznosci-publicznej.html (accessed on 20 February 2020).

37. Gminaskawina.pl, Aktualności OP: Konferencja Podsumowująca "Projekt Solarny". Available online: https://www.gminaskawina.pl/index.php?option=16\&action=news_show\&news_id=14641 (accessed on 20 February 2020).

38. Gürel, E.; Tat, M. SWOT Analysis: A Theoretical Review. J. Int. Soc. Res. 2017, 10, 994-1006. [CrossRef]

39. Energy Act, Ustawa z Dnia 10 Kwietnia 1997 r. Warszawa, Poland 1997. Available online: http://prawo.sejm. gov.pl/isap.nsf/download.xsp/WDU19970540348/U/D19970348Lj.pdf (accessed on 20 February 2020).

40. Ustawa z Dnia 19 lipca 2019 r. o Zmianie Ustawy o Odnawialnych Źródłach Energii Oraz Niektórych Innych Ustaw; Dz.U. 2019 poz. 1524; ISAP: Warszawa, Poland, 2019.

41. Polityka Energetyczna Polski do 2030 r. Warszawa, Poland, 2009. Available online: https://www.gov.pl/web/ aktywa-panstwowe/polityka-energetyczna-polski-do-2030-roku (accessed on 20 February 2020).

42. Gwizdak, K.; Jamontt-Skotis, M.; Kędzierska, K.; Łata, W.; Wikarek, E.; Siudak, J.; MłodzianowskaSynowiec, M.; Kalbrun, L. Prognoza oddziaływania na środowisko projektu Strategii Zintegrowanych Inwestycji Terytorialnych dla Krakowskiego Obszaru Funkcjonalnego; Atmoterm SA: Opole, Poland, 2014; pp. 73-108.

43. Rozporządzenie Ministra Środowiska z Dnia 13 Września 2012 r. w sprawie dokonywania oceny poziomów substancji w powietrzu. Dz. U. 2012 poz. 1032; Government Legislation Centre: Warszawa, Poland, 2012.

44. Kochańska, E. (Ed.) Determinanty Rozwoju Odnawialnych Źródeł Energii; Seria wydawnicza Acta Innovations; CBI Pro-Akademia: Łódź, Poland, 2014; ISBN 978-83-63704-19-3. 
45. Wojewódzki Inspektorat Ochrony Środowiska w Krakowie/Regional Inspectorate for Environmental Protection in Krakow. Program Państwowego Monitoringu Środowiska Województwa Małopolskiego na lata 2016-2020; WIOŚ w Krakowie: Kraków, Poland, 2015.

46. System Monitoringu Jakości Powietrza. Available online: http://monitoring.krakow.pios.gov.pl (accessed on 20 February 2020).

47. Wojewódzki Inspektorat Ochrony Środowiska w Krakowie/Regional Inspectorate for Environmental Protection in Krakow. "Małopolska Bez Smogu"—Czym Oddychają Mieszkańcy Podkrakowskich Gmin; WIOŚ w Krakowie: Kraków, Poland, 2018. article distributed under the terms and conditions of the Creative Commons Attribution (CC BY) license (http://creativecommons.org/licenses/by/4.0/). 